\title{
A Study on the Internal Structure of Heumgyeonggaknu
}

\author{
Sang Hyuk Kim ${ }^{1 \dagger}$, Yong Sam Lee ${ }^{2}$, Min Soo Lee ${ }^{2}$, Sun Young Ham ${ }^{1,2}$ \\ ${ }^{1}$ Korea Astronomy and Space Science Institute, Daejeon 305-348, Korea \\ ${ }^{2}$ Department of Astronomy and Space Science, Chungbuk National University, Cheongju 361-763, Korea
}

\begin{abstract}
Heumgyeonggaknu is a water-hammering type automatic water clock which was made by Jang Yeong-Sil in 1438. The water clock that is located in Heumgyeonggaknu consists of Suho which is equipped with 2-stage overflow. Constant water wheel power is generated by supplying a fixed amount of water of Suho to Sususang, and this power is transferred to each floor at the same time. The 1st floor rotation wheel of Gasan consists of the operation structure which has the shape of umbrella ribs. The 2nd floor rotation wheel is made so that the 12 hour signal, Gyeong-Jeom signal, and Jujeon constitute a systematic configuration. The 3rd floor rotation wheel is made so that the signal and rotation of Ongnyeo and four gods can be accomplished. Based on the above conceptual design, this paper analyzed the internal signal generation and power transmission of Heumgyeonggaknu.
\end{abstract}

Keywords: Heumgyeonggaknu, water-hammering method, Geolteok, Jujeon

\section{INTRODUCTION}

This study revised and supplemented the proceedings data of "2012 International Symposium on Historical Astronomy" (Held in Seoul, Korea, 17-19 May 2012), and added the analysis of internal parts.

The observation of astronomical phenomena (天文) was a critical factor in the King of Joseon Dynasty governs the country. A number of astronomical instruments (天文儀器) were used to understand the movements occurring in the sky. As the astronomical instruments of those days were mostly installed in a garden in the palace, it was inconvenient for the King to figure out the time. ${ }^{1}$ Hence, the water clock for the King was made by building Heumgyeonggak (欽敬閣) pavilion on the western side of Cheonchujeon (千秋殿) pavilion and installing Heumgyeonggaknu (欽敬閣漏, alias 'Ongnu') within Heumgyeonggak pavilion. ${ }^{2}$ In this study, the internal components of Heumgyeonggaknu were analyzed based on the record of ${ }^{\circledR}$ Annals of the Joseon Dynasty (朝鮮王朝實 錄)』which introduces the structure of Heumgyeonggaknu made by Jang Yeong-Sil (蔣英實). Especially, the operation mechanism was systematically examined by presenting the internal parts and configuration as schematic diagrams.

\section{SURVEY OF HISTORICAL RECORDS AND EXTERNAL STRUCTURE}

\subsection{History of Heumgyeonggaknu}

Table 1 summarizes the historical records survey of Heumgyeonggak and Heumgyeonggaknu collected from ${ }^{『}$ Annals of the Joseon Dynasty』, ${ }^{\circledR}$ Seungjeongwonilgi (承政院 日記)』, ${ }^{\circledR}$ Gukjobogam (國朝寶鑑)』, ${ }^{\circledR}$ Jeungbo-munheonbigo (增補文獻備考)』、

${ }^{1}$ Sejong sillok, 80:5a:line 11; 且諸器皆設於後苑, 難以時時占察.

${ }^{2}$ Sejong sillok, 80:5a:line 11 13; 乃於千秋殿西庭, 建一間小閣, 糊紙爲山, 高七 尺許, 置於其中. 內設玉漏機輪, 以水激之.

Received Jan 28, 2013 Revised Mar 12, 2013 Accepted Mar 22, 2013 †Corresponding Author

E-mail: astro91@kasi.re.kr

Tel: +82-42-865-2046, Fax: +82-42-861-5610 
Table 1. Records of Heumgyeonggak and Heumgyeonggaknu.

\begin{tabular}{|c|c|c|c|}
\hline $\begin{array}{l}\text { King Reign Year } \\
\text { (Year-Month-Day) }\end{array}$ & Contents & Historical Records & Remark \\
\hline $\begin{array}{l}\text { Sejong } 19 \\
(1437-4-15)\end{array}$ & The external form of Heumgyeonggaknu was introduced. & Sejong Sillok & 景福宮 \\
\hline $\begin{array}{l}\text { Sejong } 20 \\
(1438-1-7)\end{array}$ & $\begin{array}{l}\text { Heumgyeonggaknu was completed. } \\
\left\ulcorner\text { Heumgyeonggakgi } i_{\perp}\right.\end{array}$ & $\begin{array}{l}\text { Sejong Sillok } \\
\text { Gukjobogam }\end{array}$ & 卷7, 申淑舟 \\
\hline $\begin{array}{l}\text { Seongjong } 21 \\
(1490 \text {-Yun } 9-6)\end{array}$ & $\begin{array}{l}\text { Gasan's figures and internal striking devices were left in a state of damage for } \\
\text { many years. }\end{array}$ & Seongjong Sillok & \\
\hline $\begin{array}{l}\text { Seongjong } 21 \\
(1490-\text { Yun } 9-6)\end{array}$ & $\begin{array}{l}\text { The repair of Heumgyeonggaknu was completed and it was operated only for } 10 \\
\text { days of the vernal equinox, summer solstice and autumnal equinox. } \\
\text { Introduce the role of Haeja (海子) and Jujeon (籌箭). }\end{array}$ & Seongjong Sillok & \\
\hline $\begin{array}{l}\text { Jungjong } 4 \\
(1509-11-8)\end{array}$ & $\begin{array}{l}\text { Inherit the royal heritage of King Sejong through the renovation of } \\
\text { Heumgyeonggaknu after gathering extensive opinions on this process. }\end{array}$ & Jungjong sillok & \\
\hline $\begin{array}{c}\text { Jungjong } 12 \\
(1517-11-25)\end{array}$ & Correction of Heumgyeonggaknu is in progress. & Jungjong sillok & \\
\hline $\begin{array}{l}\text { Jungjong } 38 \\
(1543-11-2)\end{array}$ & Uigi of Heumgyeonggak's Gasan was discussed. & $\begin{array}{l}\text { Jungjong sillok } \\
\text { Gukjobogam }\end{array}$ & 卷20, 申淑舟 \\
\hline $\begin{array}{l}\text { Myeongjong } 5 \\
(1550-6)\end{array}$ & $\begin{array}{l}\text { King Myeongjong ordered Sang Jin (商震), who is in charge of Gwansanggam (觀 } \\
\text { 象監), and Kim Ik Su (金益壽) to renovate figures for match with the Binpungdo. }\end{array}$ & Gukjobogam & 卷22, 申淑舟 \\
\hline $\begin{array}{l}\text { Myeongjong } 5 \\
(1550-8-3)\end{array}$ & Prepare for the destruction of Heumgyeonggaknu. & Myeongjong sillok & \\
\hline $\begin{array}{c}\text { Myeongjong } 5 \\
(1550-11-6)\end{array}$ & Uigi was repaired. It was installed on either side of the thorn. & Myeongjong sillok & \\
\hline $\begin{array}{c}\text { Myeongjong } 8 \\
(1553-9-14)\end{array}$ & Gyeongbokgung Palace burned to the ground and Heumgyeonggak also burned. & $\begin{array}{l}\text { Myeongjong sillok } \\
\text { Gukjobogam }\end{array}$ & 卷22, 申淑舟 \\
\hline $\begin{array}{c}\text { Myeongjong } 8 \\
(1553-12-26)\end{array}$ & The foundation of Heumgyeonggak was finished. & Myeongjong sillok & \\
\hline $\begin{array}{l}\text { Myeongjong } 9 \\
(1554-8-2)\end{array}$ & Reconstruction of Heumgyeonggak was completed. & $\begin{array}{l}\text { Myeongjong sillok } \\
\text { Sinjeung Dongguk } \\
\text { yeoji seungnam } \\
\text { Yeollyeosilgisul }\end{array}$ & $\begin{array}{l}\text { 卷 } 2 \text {, 李荇 } \\
\text { 卷3, 李肯翊 }\end{array}$ \\
\hline $\begin{array}{c}\text { Myeongjong } 9 \\
(1554-8-19)\end{array}$ & King Myeongjong congratulated on the reopen of Heumgyeonggak. & Myeongjong sillok & \\
\hline $\begin{array}{l}\text { Gwanghaegun } 5 \\
(1613-8-1)\end{array}$ & $\begin{array}{l}\text { The construction work is progressing despite the request of discontinue from } \\
\text { Saganwon (司諫院) and Saheonbu (司憲府). }\end{array}$ & Gwanghaegun ilgi & $\begin{array}{l}\text { After Japanese Invasion } \\
\text { of Korea in } 1592\end{array}$ \\
\hline $\begin{array}{c}\text { Gwanghaegun } 5 \\
(1613-8-30)\end{array}$ & The chief of Heumgyeonggak construction work reported the building site. & Gwanghaegun ilgi & \\
\hline $\begin{array}{l}\text { Gwanghaegun } 6 \\
\quad(1614-7-9)\end{array}$ & $\begin{array}{l}\text { The repair of Heumgyeonggak's internal devices, the shape of Gasan (假山) and } \\
\text { vegetation and Sasin (司辰) was discussed. }\end{array}$ & Gwanghaegun ilgi & \\
\hline $\begin{array}{l}\text { Gwanghaegun } 6 \\
(1614-7-18)\end{array}$ & $\begin{array}{l}\text { King Gwanghaegun ordered to repair of Heumgyeonggak's west side water clock } \\
\text { expeditiously. }\end{array}$ & Gwanghaegun ilgi & \\
\hline $\begin{array}{c}\text { Gwanghaegun } 6 \\
(1614-9-14)\end{array}$ & $\begin{array}{l}\text { The chief of Heumgyeonggak construction work reported the completion of } \\
\text { Cheonjiho (天池噯, a water pot for water expel). }\end{array}$ & Gwanghaegun ilgi & \\
\hline $\begin{array}{l}\text { Gwanghaegun } 8 \\
(1616-1-16)\end{array}$ & $\begin{array}{l}\text { Correction of Heumgyeonggak. Park Ja Heung (朴自興) was named vice chief of } \\
\text { Heumgyeonggak correctional administration (欽敬閣 矯正廳). }\end{array}$ & Gwanghaegun ilgi & \\
\hline $\begin{array}{l}\text { Gwanghaegun } 8 \\
(1616-8-12)\end{array}$ & Correction of Heumgyeonggak is nearing completion. & Gwanghaegun ilgi & \\
\hline $\begin{array}{l}\text { Gwanghaegun } 8 \\
(1616-8-20)\end{array}$ & $\begin{array}{l}\text { Heumgyeonggak correctional administration reported the correction of water } \\
\text { clock for night (夜漏). The incorrect time of water clock for night is caused by } \\
\text { waste materials of muddy water. }\end{array}$ & Gwanghaegun ilgi & \\
\hline $\begin{array}{l}\text { Gwanghaegun } 8 \\
(1616-8-29)\end{array}$ & $\begin{array}{l}\text { Heumgyeonggak correctional administration reported the correction process of } \\
\text { water clock for night. }\end{array}$ & Gwanghaegun ilgi & \\
\hline $\begin{array}{l}\text { Gwanghaegun } 9 \\
(1617-1-18)\end{array}$ & $\begin{array}{l}\text { King Gwanghaegun ordered chief of Gwansanggam (觀象監) and many of his } \\
\text { officials to correct Heumgyeonggak since the vernal equinox. }\end{array}$ & Gwanghaegun ilgi & \\
\hline $\begin{array}{c}\text { Hyojong } 6 \\
(1655-11-17)\end{array}$ & A building planned to build on the site of Heumgyeonggak. & $\begin{array}{l}\text { Hyojong sillok } \\
\text { Gukjobogam }\end{array}$ & 卷 28 , 申淑舟 \\
\hline $\begin{array}{l}\text { Hyojong } 6 \\
(1655-11-23)\end{array}$ & $\begin{array}{l}\text { Demolition of Heumgyeonggak and the use of its old woods and roof tiles were } \\
\text { discussed. }\end{array}$ & Hyojong sillok & \\
\hline $\begin{array}{l}\text { Hyojong } 6 \\
(1655-12-4)\end{array}$ & $\begin{array}{l}\text { Kim Yuk (金堉) contended the irrationality of demolition of Heumgyeonggak for } \\
\text { construction of queen mother's building on its site. }\end{array}$ & $\begin{array}{l}\text { Hyojong sillok } \\
\text { Imhapilgi } \\
\text { Jamgokyugo }\end{array}$ & $\begin{array}{l}\text { 卷 } 3 \text {, 李裕元 } \\
\text { 卷 } 6 \text {, 金堉 }\end{array}$ \\
\hline
\end{tabular}


Table 1. Continue.

\begin{tabular}{|c|c|c|c|}
\hline $\begin{array}{l}\text { King Reign Year } \\
\text { (Year-Month-Day) }\end{array}$ & Contents & Historical Records & Remark \\
\hline $\begin{array}{l}\text { Hyojong } 6 \\
(1655)\end{array}$ & $\begin{array}{l}\text { Two buildings were constructed on former site of Heumgyeonggak for queen } \\
\text { mother. }\end{array}$ & $\begin{array}{c}\text { Gukjobogam } \\
\text { Gunggwolji } \\
\text { Imhapilgi } \\
\text { Sinjeung Dongguk yeoji } \\
\text { seungnam }\end{array}$ & $\begin{array}{l}\text { 怣 } 38, \text { 申淑舟 } \\
\text { 昌德宮志 } \\
\text { 替13, 李裕元 } \\
\text { 卷 } 2, \text { 李荇 }\end{array}$ \\
\hline $\begin{array}{l}\text { Yeongjo } 46 \\
\quad(1770)\end{array}$ & $\begin{array}{l}\text { Heumgyeonggak was reconstructed for storage of a carved stone astronomical } \\
\text { chart (天象列次分野之圖) which was found in Gyeongbokgung Palace. }\end{array}$ & $\begin{array}{c}\text { Jeungbo munheon bigo } \\
\text { Seungjeongwon ilgi } \\
\text { Imhapilgi } \\
\text { Yeollyeosilgisul }\end{array}$ & $\begin{array}{c}\text { 象緯考 卷3 } \\
\text { 卷3, 李裕元 } \\
\text { 別集 卷7, 李肯䄰 }\end{array}$ \\
\hline $\begin{array}{c}\text { Jeongjo } 18 \\
(1794-3-24)\end{array}$ & $\begin{array}{l}\text { The repair order of Heumgyeonggak was given. Heumgyeonggaknu already } \\
\text { disappeared. }\end{array}$ & Jeongjo sillok & \\
\hline $\begin{array}{c}\text { Gojong } 13 \\
(1876-11-4)\end{array}$ & Gyeongbokgung Palace burned to the ground and Heumgyeonggak also burned. & Gojong sillok & 景福宮 \\
\hline
\end{tabular}

*Sejong (世宗), Seongjong (成宗), Jungjong (中宗), Gwanghaegun (光海君), Myeongjong (明宗), Hyojong (孝宗), Yeongjo (英祖), Jeongjo (正祖), Gojong(高 宗), Gukjobogam (國朝寶鑑, Precious mirror for succeeding reigns), Sinjeung Dongguk yeoji seungnam (新賭東國興地勝覽, newly verified survey of the geography of the Eastern Kingdom), Yeollyeosilgisul(燃僽室記述, narratives of Yeolyeosil), Imhapilgi (林下筆記), Jamgokyugo (潛谷遺稿), Gunggwolji (宮 關志), Jeungbo munheon bigo (增補文獻備考, expanded version of the reference compilation of documents on Korea), Seungjeongwon ilgi (承政院日記), sillok (實錄, Annals of the Joseon Dynasty), ilgi (daily records), Yun(閏, intercalary month)

增東國舆地勝覽)』, and individual collection of works. ${ }^{3}$ According to the historical records, the Heumgyeonggak and Heumgyeonggaknu were first mentioned in the 1437 (the 19th year of the reign of King Sejong) record of Sejong Sillok. This record stated that the Heumgyeonggak is located in the western side of Gyeongbokgung Cheonchujeon, and explained the external structure of Heumgyeonggaknu. The Heumgyeonggaknu was completed in January 1438, and King Sejong ordered Kim Don (金墩, 1385 1440) to compose the writing for record. This record describes the external form and operation structure of Heumgyeonggaknu. However, the detailed operation mechanism of the internal structure is not mentioned in this record, but it mentioned the waterhammering method only. The Heumgyeonggaknu remained in existence through maintenance and repair, but it was burned down along with Heumgyeonggak when there was a big fire at Gyeongbokgung palace in 1553 (the 8th year of the reign of King Myeongjong). In the following year, the Heumgyeonggak was reconstructed in Gyeongbokgung palace, but it was again destroyed by fire during Japanese Invasion of Korea in 1592 (壬辰倭亂, the 25th year of the reign of King Seonjo).

The second reconstruction of Heumgyeonggak began in 1613 (the 5th year of the reign of Gwanghaegun) (Ahn 2010). ${ }^{4}$ The reconstruction was carried out in Changdeokgung (昌德宮) palace Seorinmun (瑞燐門) gate considering the situation of the times that the Beopgung (法宮) was moved to Changdeokgung palace and Changgyeonggung (昌慶宮) palace. The construction work is processing despite the request of discontinue from Saganwon (司諫院, the government office of inspection) and
Saheonbu (司憲府, the government office of advice) and the Heumgyeonggak was completed over a period of 1 year. As there were several records of correction during the reign of King Gwanghaegun, it is thought that the water clock was also made and operated in Heumgyeonggak. Since then, there was no re cord on Heumgyeonggak and Heumgyeonggaknu. In 1655 (the 6th year of the reign of King Hyojong), there was the record that King Hyojong constructed Mansujeon (萬壽殿) pavilion at the site of Heumgyeonggak to support the Queen Mother (Kim 2002). ${ }^{5}$

In 1770 (the 46th year of the reign of King Yeongjo), the Heumgyeonggak was again mentioned in the record for storing the carved-stone astronomical chart (天象列次 分野之圖, Cheonsang-yeolcha-bunya-jido) discovered in Gyeongbokgung. However, as the Heumgyeonggaknu was not particularly mentioned in the historical records, it is thought that the Heumgyeonggaknu was not operated. When the Gyeongbokgung was rebuilt over 3 years from 1865 (the 2nd year of the reign of King Gojong) to 1868 (the 5th year of the reign of King Gojong), the Heumgyeonggak was also newly reconstructed, but there was no record on Heumgyeonggaknu. In 1876 (the 13th year of the reign of King Gojong), the Heumgyeonggak was again burned down when there was a

${ }^{3}$ Integrated Database of Korean Classics from the Institute for the Translation of Korean Classics was used.

${ }^{4} \mathrm{Ahn}(2010)$ introduced that $\ulcorner$ Heumgyeonggak-yeonggeon-uigwe (欽敬閣營建 儀軌)」 records the reconstruction procedure and result of Heumgyeonggak in 1613, and reported that the Uigwe was kept in Oegyujanggak and burned in a fire by French Navy in 1866.

${ }^{5}$ Kim (2002) examined $\ulcorner$ Changdeokgung-mansujeon-suridogam-uigwe (昌德 宮萬壽殿修理都監儀軌)」, and reported that the Changdeokgung Mansujeon Suridogam was installed on August 4, 1656 (the 7th year of the reign of King Hyojong) and the Heumgyeonggak was pulled down on August 11, 1656. 
Table 2. The external form and working mechanism of Heumgyeonggaknu in $\ulcorner$ Chronicle of Heumgyeonggaknu」(or $\ulcorner$ Heumgyeonggakgi $\lrcorner$ ) ( $『$ Sejong Sillok $k_{\unlhd}$ 80:5a:line 5 6a:line 8).

\begin{tabular}{|c|c|}
\hline No & Contents \\
\hline 1 & $\begin{array}{l}\text { Dimensions ( } 7 \text { foot height of Gasan) and Operating Principals } \\
\text { (water-hammering method) of Heumgyeonggaknu. }\end{array}$ \\
\hline 2 & $\begin{array}{l}\text { Sun Movement Device runs in accordance with } 4 \text { Seasons (role of } \\
\text { astronomical clock). }\end{array}$ \\
\hline 3 & $\begin{array}{l}\text { Ongnyeo (I) on the top of mountain ring a bell every hour and } 4 \\
\text { gods (神) rotate } 90 \text { degree. }\end{array}$ \\
\hline 4 & lanation of time signal puppets on Sibodae (時報臺). \\
\hline 5 & card and the \\
\hline 6 & $\begin{array}{l}\text { Explanation of Device and Gwanin on Nusudae (漏水臺): Bowl of } \\
\text { Uigi gradually stands straight when the water fills the bowl and } \\
\text { then the water in bowl flushes when it full. }\end{array}$ \\
\hline 7 & $\begin{array}{l}4 \text { seasons of Binpungdo (閑風圖) and puppets were expressed on } \\
\text { the farm land of Gasan. }\end{array}$ \\
\hline
\end{tabular}

fire at Gyeongbokgung. Based on the above historical records, the Heumgyeonggaknu which was operated following the tradition of King Sejong's era is estimated to have been used until 1617 (the 9th year of the reign of Gwanghaegun).

\subsection{Structure and Water-hammering Method of Heumgyeonggaknu}

The external form of Heumgyeonggaknu and the operation of time signal puppets are described in ${ }^{\circledR}$ Sejong Sillok (世 宗實錄)』. ${ }^{6}$ The historical records include the specification and working principle of Heumgyeonggaknu, Sun movement device, and the detailed operation mechanisms such as the operation of 4 Ongnyeo I (玉女, jade female immortals) and four gods (神; 青龍-Blue Dragon, 白虎-White Tiger, 朱雀-Red Bird, and 玄武-Black Tortoise) at the top of the mountain, the operation of Sibodae (時報臺, time signal platform) and time signal puppets at the foot of the mountain, the operation of 12 Ongnyeo II and twelve gods (神; 子, 丑, 寅, 卯, 辰, 已, 午, 未, 申, 西, 戊, and 亥) on the flatland, and the operation of Nusudae (漏水臺, platform of Uigi) (Table 2). ${ }^{7}$ The 1/6 scale model of Heumgyeonggaknu was recently restored based on the our detailed analysis regarding the external structure of Heumgyeonggaknu (Fig. 1). ${ }^{8}$

The fixed quantity supply of water and constant speed operating of the water wheel is most important to the waterhammering type water clock. Kim et al. (2011) suggested that a fixed quantity water in Uigi (歌器, inclining vessel) which is supplied from southern Gwanin (官人, government official)'s golden bottle spilled into Nusudae as time passed and this water move into a small vessel which is hanging from the water wheel in Heumgyeonggaknu and then this water-filled device is operating Cheonhyeong system (天衡, oriental escapement device).

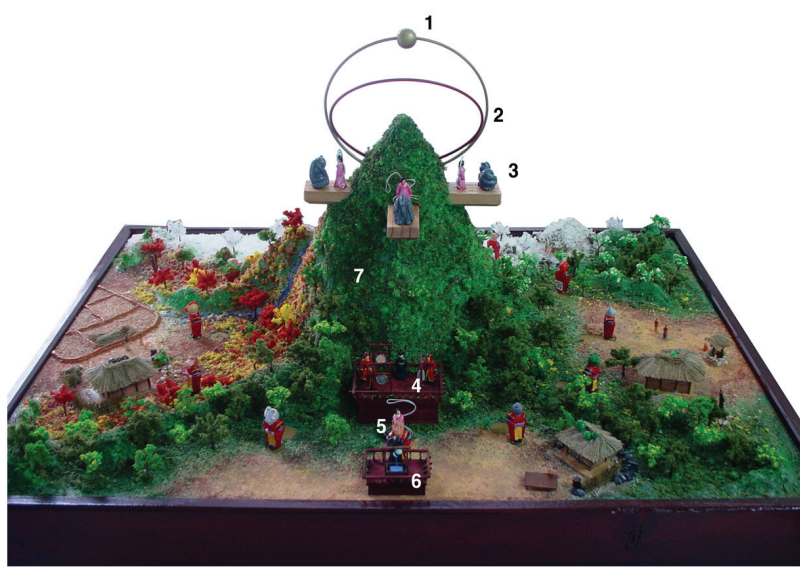

Fig. 1. Miniature of Heumgyeonggaknu $(1 / 6$ size, $80 \times 60 \times 45(h) \mathrm{cm})$. 1: Sun apparatus, 2: ecliptic ring and equatorial ring, 3: Ongnu(II) and four gods, 4: Sibodae (Sasin and Musa), 5: Ongnu(I) and twelve gods, 6: Nusudae (Gwanin and Uigi), 7: Gasan

However, a fixed quantity water is already supplied to Sususang (授水箱, water receiving small vessel) from the water clock with the overflow function which is installed inside Gasan (假山, imitation mountain). Therefore, it is hard to be regarded as a mechanism which again connects Nusudae and Sususang with Cheonhyeong system. Regarding the operation mechanism of water-hammering type Honsang, Lee \& Kim (2012) recently introduced a mechanism which is controlled by Cheonhyeong system when the water of water clock is contained in Sususang. The water wheel control method of Heumgyeonggaknu (made in 1438) is thought to be similar to the water wheel control method of Honui (渾儀, armillary sphere) and Honsang (渾 象, celestial globe) (made in 1435) as they were produced in the same period. Kim (2012) suggested that the motif of operation mechanism for this water wheel control is the control method of Chinese water-driven astronomical clock tower (水運儀象臺, Shui yün i hsiang t'ai).

${ }^{6}$ Sejong sillok, 80:5a:line 5 6a:line 8; 欽敬閣成。大護軍蔣英實經營之, 其规 模制度之妙, 皆出㤐裁, 閣在景福宮燕寢之傍. 上命右承旨金敦, 作記日: 若 稽帝王發政成務, 必先於明曆授時, 而授時之要, 在於觀天察候, 此璣衡儀表 所由設也。然考驗之方, 極精至密, 非一器一象所能取正. 我主上殿下命似 司制諸儀象, 若大小簡儀渾儀渾象仰釜日㫡日星定時圭表禁漏等器, 皆極精 巧, 夏越前規, 猶虑制度未精……閣既成, 命臣書其事, 謹述梗概, 拜手稽 首以獻.

${ }^{7}$ For the expression and meaning of four gods and twelve gods, refer to pp. 81 82 of Kim et al. (2011).

${ }^{8}$ In the case of 12 puppets on the flatland in Heumgyeonggaknu, only the puppet which corresponds to the specific time is standing up, and other puppets are lying face down. The scale model in Fig. 1 was made so that every puppet is standing up.

${ }^{9}$ For the study of Kim et al. (2011), it is hard to be regarded as the key device related with water-hammering type control considering that the Uigi is installed separately as stated in the literature record (Myeongjong Sillok 10:92a:10 14). (Myeongjong Sillok 10:92a:10～14; 領觀象監事李芑啓日 前者, 以欽敬閣歌器, 虛而不歌, 故今改造而進. 然此器, 非但置諸欽敬閣, 乃古聖人 勸戒之器, 常置諸左右, 可注水而觀省也. 荷子畫此器, 而且有臺. 故具臺而進. 傳日 知道. 此乃聖人勸戒之器, 當置諸坐側而觀省焉. 其貯水器及注水器, 竝 造入之.). 


\section{ANALYSIS OF INTERNAL COMPOSITION}

\subsection{Haeja and Jujeon}

${ }^{『}$ Seongjong Sillok $k_{\unlhd}$ May 10, 1493) introduced Haeja (海子, water containing large vessel) which is a vessel that supplies water in Heumgyeonggaknu. The Haeja is made of copper (銅) and iron (鐵). Lead is commonly used for repairing Haeja, but the lead is damaged when exposed to water for a long time. In that case, the plank at the bottom decays due to leaking water which causes problem in maintenance. ${ }^{10}$ The water contained in Haeja is also supplied to pond which is shown in the operation of Giryun (機輪, mechanism wheel) and exterior of Gasan, waterfall, and Uigi. ${ }^{11}$

The water in Haeja is used to induce an automatic striking by triggering Jujeon (籌箭, calculating apparatus of stick) of Heumgyeonggaknu. ${ }^{12}$ The role of Jujeon seems to be similar to the rod (hereinafter, 'Bujeon (浮箭, float-rod)') in Borugaknu (報漏閣漏, alias 'Jagyeongnu'). The Bujeon of Borugaknu rises when the water flows into Susuho. The rising Bujeon touches the ball that corresponds to 12-Si (時, 1-Si; double hours in modern time), 5-Gyeong (更, 1-Gyeong; divide night into five equal parts), and 5-Jeom (點, 1-Jeom; divide Gyeong into five equal parts), which generates the signal for striking the bell, drum, and gong.

No clear explanation exists for the operation of Jujeon in Heumgyeonggaknu, but it can be summarized as two kinds of views. One hypothesis is that the water inflow from Haeja raises the device of Jujeon, similar to the Bujeon of Borugaknu. The inflow of water operates Jujeon, and the corresponding ball controls 37 time signal puppets which are located at the top of the mountain, at the foot of the mountain, and on the flatland, and strikes the bell, drum, and gong. However, in this case, there is no need for 'Ongnugiryun (玉漏機輪)' to be operated in contact with water, and a complicated mechanism would be required which has independent operation device for each floor.

The other hypothesis is that the water from Haeja is supplied to the water clock and this water operates the water wheel, and this power is transferred to Giryun and raises the device of Jujeon. In the power system of Borugaknu, the water clock and time signal system operate independently, and these two operation mechanisms are connected by a device called Bangmok (方木, narrow wooden casing). The Bangmok plays a role in converting the analog flow of water clock to digital signal (Nam 2002). When the water

${ }^{10}$ Seongjong sillok, 277:9b:line $8 \sim 10$; 海子用銅鐵而罅隙補以鑞鐵, 鑞鐵久沈 於水則必消鍑, 若每令貯水, 則滲漏其下, 板子腐朽, 隨後改板, 勢亦甚難矣.

${ }^{11}$ Seongjong sillok, 277:9b:line $7 \sim 8$; 此閣則有蓮池有欹器又有瀑布, 故常貯水

於海子.

${ }^{12}$ Seongjong sillok, 277:9b:line 13; 貯水流注激籌箭, 使之自擊. in Haeja is sent to the water wheel in Heumgyeonggaknu, the digital signal is generated with the use of Sususang and Cheonhyeong system. The operation of water wheel is not continuous, and plays a role in generating a constant signal. Therefore, the motion of Giryun and the rise of Jujeon can transfer the power through the rotation of Giryun even though there is no inflow of water.

To further add to the above discussion, the reason that the inflow of water supplied from Haeja is not likely to move Jujeon directly is as follows. First, it is because of the explanation on the operation mechanism called 'Ongnu-giryun-sugyeokji (玉漏機輪水激之)'. For Gasan, using a single column as the rotation axis (Giryun) is efficient for making the time signal puppets at the top of the mountain, at the foot of the mountain, and on the flatland have a unified motion and signal system. This rotation axis has a constant speed by the constant water wheel torque. In addition, if the movement of Sibodae at the foot of the mountain which strikes the bell, drum, and gong is designed to use extra inflow of water, it is difficult to exactly match the motion of time signal puppets at the top of the mountain and on the flatland at the same time. Therefore, in order to accomplish a systematic motion of time signal puppets at the top of the mountain (relevant to the operation of four gods and Ongnyeo I), at the foot of the mountain (relevant to the operation of Sasin, Jongin, Goin, and Jeongin), and on the flatland(relevant to the operation of twelve gods and Ongnyeo II) by rotating Giryun with the torque generated from the water wheel, it is best to operate a single Giryun.

Hence, the meaning of 'The water in Haeja induces an automatic striking by triggering Jujeon.' stated in the historical records seems to indicate that the water supplied from Haeja operates the water wheel, and the water wheel transfers the physical power (mechanical power) to Giryun. Accordingly, the power transferred from Giryun is transferred from the top of the mountain to the flatland, and it is expected that there existed a device in Sibodae at the foot of the mountain that corresponds to the Bujeon and Bangmok of Borugaknu, which automatically regulates the striking number and order. Therefore, the water in Haeja stated in the historical records can be understood as the fundamental power which triggers Jujeon.

\subsection{Internal Ball Mechanism and Suho}

${ }^{『}$ Gwanghaegun Ilgi』(July 9, 1614) mentioned the operation and trigger of ball that is occurring in Heumgyeonggaknu, the contents of large $\cdot$ medium $\cdot$ small bronze vessels, the material for Japsang (雜像) at the top of Gasan, and the 
information on the rise and set of the Sun and the Moon..$^{13}$ First, regarding the operation and trigger of ball, a connecting medium was mentioned which was not presented in the previous explanation of Haeja and Jujeon. In other words, it presented important contents which reveal the existence and role of ball. The sentence, 'The vessel is filled with water, the water moves the ball, and the ball strikes the machine (以器盛水, 以水運鈴, 以鈴觸動機械).' indicates that the water contained in Sususang of water wheel is the driving force which operates the ball. This ball triggers a mechanical device, and the mechanical device is thought to be related with Jujeon. In addition, it was presented that the tube for the movement of water and ball is made of copper.

For the size of Suho which constitutes the water clock, 3 kinds were mentioned as large, medium, and small. The big $H o$ (喆) is thought to be the water supply device, and the medium $\mathrm{Ho}$ and small $\mathrm{Ho}$ seem to be the Suho which has the overflow function and Pyesuho (廢水壼) which receives the overflowed water. Regarding the large, medium, and small Suho, Hahn et al. (2000) considered that the medium Ho has the overflow function with 3-stage arrangement, and that the Suho was located outside Gasan due to the size of this 3 -stage arrangement. Though the possibility that the water clock was located outside Gasan cannot be completely ruled out, the exact position of water clock is not explained in the record of $\left\ulcorner\right.$ Heumgyeonggakgi」 $\left({ }^{『}\right.$ Seongjong Sillok』January 7, 1438) of King Sejong's era.

In the study of the internal water-hammering type mechanism of Lee Min-Cheol's armillary clock, through the caparison with the Chinese water-driven astronomical clock tower, Park (2011) estimated that the diameter of water wheel was $82.8 \mathrm{~cm}$, the number of Sususang was 12 or 16 , and the size of Suho was less than 2-cheok which are smaller than the Chinese water-driven astronomical clock tower, and that the water wheel rotated 45 times per day. However, the historical record of Heumgyeonggaknu stated that ' 5,000 to 6,000 geun (斤) of bronze' was used for the water clock, indicating that the size is not small. In this study, the structure was estimated considering both of the two possibilities that the water clock is located inside or outside Gasan. In addition, regarding the water clock configuration of Borugaknu, Nam (2002) placed a large water pot at the top, arranged 2-stage (upper and lower, 2 pieces) Suho below the pot which has an overflow device at the lower Suho, and positioned 1-stage (1 piece) Pyesuho which receives the overflowed water. It is expected that this

${ }^{13}$ Gwanghaegun ilgi, 80:7b:line 9～14; 閣內凡日月出入、書夜刻漏遲速, 皆以 機械篇之. 以器盛水, 以水運鈴, 以鈴觸動機械, 故鈴路水道, 皆以熟銅鐵篇之, 己鹎鑄成大中小銅器者, 不帝五六千斤。皆自臣曹, 拮据辦出, 一應采色、銅 鐵之價, 不敢別定於外方, 以貽民算. 至於假山山形, 草木之形, 司神等人像物 像, 以木造作者, 必須寒布着漆, 然後可保經露不壞, 以至永久. configuration could also be applied to the water clock of Heumgyeonggaknu. As for Heumgyeonggaknu, considering that the water in Haeja is supplied to water clock, it is thought that the Haeja corresponds to the large water pot of Borugaknu, and there may have been 2-stage Suho below Haeja. When a fixed amount of water by the overflow device is combined with Cheonhyeong system, the water wheel can be controlled at a constant time interval. For example, if the flow speed of water supplied from Suho gets slower, the operating time of Cheonhyeong also gets slower, and if the flow speed gets faster, the operating time also gets faster. Therefore, it is expected that the water-hammering type water clock which consists of water wheel and Cheonhyeong system is generally composed of 2-stage Suho with an overflow function and 1-stage Pyesuho.

The following is mentioned regarding Japsang at the top of Gasan and the Sun and the Moon. It was stated that 'Among the statues such as the mountain shape of Gasan, the form of trees and plants, and Sasin (司辰, hour-jack), those made of wood should be wrapped with hemp cloth and lacquered (至於假山山形, 草木之形, 司神等人像物像, 以木造作者, 必須寒布着漆)! This is the part that showed the material and durability of Gasan and Japsang. With regard to the movement of celestial bodies, it was stated that 'The Sun and the Moon rise and set (日月出入)'. However, the presence of Moon is not mentioned in $\ulcorner$ Heumgyeonggakgi」. The Heumgyeonggaknu of King Sejong's era was burned down in 1553 when there was a fire at Gyeongbokgung. The Heumgyeonggak was reconstructed in 1554, but it was again destroyed during Japanese Invasion of Korea in 1592. It is thought that the Moon movement function was later added to the Heumgyeonggaknu that was newly made in 1614 .

\section{CONCEPTUAL DESIGN OF OPERATION MECHANISM}

\subsection{Power Mechanism}

Needham et al. (1986) regarded the power which is applied to Heumgyeonggaknu as the buoyancy from the inflow of water. In other words, it was considered that the force generated when a buoy is raised acts as torque. This method is characteristic of the water clock devised by AlJajari in the 13th century in Islam (Hill 1989). By analyzing the record of ${ }^{『}$ Sejong Sillok』, Kim (2012) suggested that it is more likely to be the water wheel power which rotates at a constant speed, similar to the Chinese water-driven astronomical clock tower that was developed earlier than the one made in Islam. The internal power transmission 


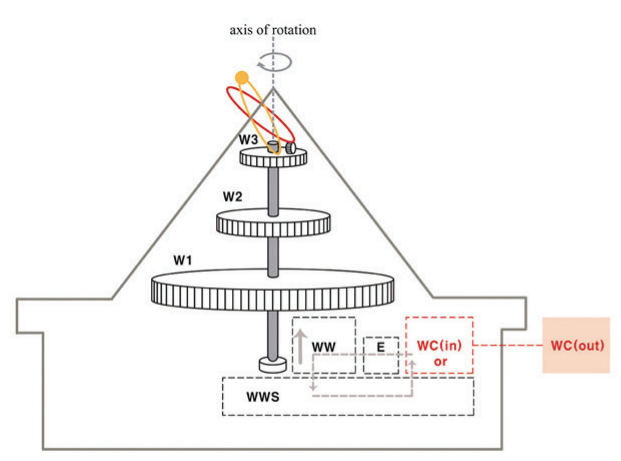

(a)

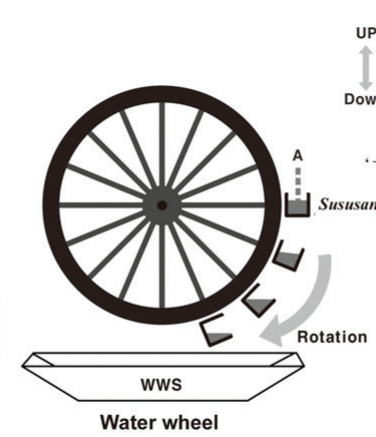

Water wheel

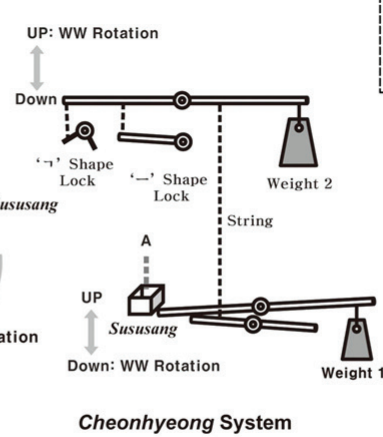

(b)

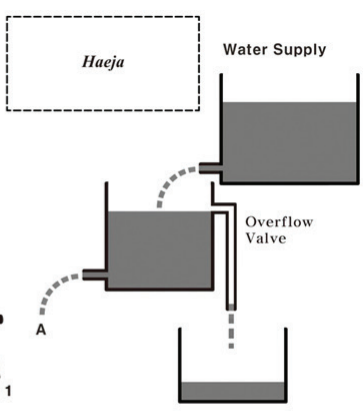

Water Clock (Suho)

Fig. 2. Internal Structure of Heumgyeonggaknu. (a) Keys map of Heumgyeonggaknu's inside. WC: water clock, WW: water wheel, E: escapement, WWS: waste water system, W1: wheel 1 (base), W2: wheel 2 (time signal platform), W3: wheel 3 (top of a mountain). (b) Power supply mechanism of Heumgyeonggaknu (Lee \& Kim 2012).

system of Heumgyeonggaknu is shown in Fig. 2.

Fig. 2a schematically shows the interior of Gasan in Heumgyeonggaknu. The water supplied from the water clock (WC) operates the water wheel (WW), and the power generated from the water wheel operates Giryun and rotation wheels (W1, W2, and W3). The water used for the operation of water wheel is contained in Pyesuho system (WWS) below the water wheel, and this water is again supplied to the water clock. In Fig. 2a, the dashed arrow represents the flow of water, and the solid arrow represents the flow of power. The position of water clock is shown considering both the exterior of Gasan (WC(out) position) and the interior of Gasan (WC(in) position). Fig. 2b shows the Cheonhyeong system (天衡裝置) which has the escapement device that generates constant power for the water-hammering type operation. ${ }^{14}$ The water is supplied from the water clock to Sususang of water wheel. In order to let Sususang contain a fixed amount of water, a balance device was attached where a weight is hung. Therefore, the water is contained as much as the mass of weight, and the generated power is transferred to the water wheel.

\subsection{Internal Structure of the Time Signal System}

The power transferred to the water wheel rotates the Giryun of Heumgyeonggaknu once per day. The Giryun consists of rotating wheels which constitute the 1st, 2nd, and 3rd floors. The 1st floor rotation wheel (W1) transfers

${ }^{14}$ Regarding this part, Kim et al. (2011) stated that "by the working mechanism of Nusudae that had the escapement system" (Kim et al. 2011, p.84). However, in the following research, the Nusudae was analyzed as the space which simply accommodates Uigi. Thus, a fixed quantity of water is directly supplied to Sususang of water wheel.

${ }^{15}$ Sejong sillok, 65:2b:line 12; 則足端鐵輪, 順轉銅板而下.

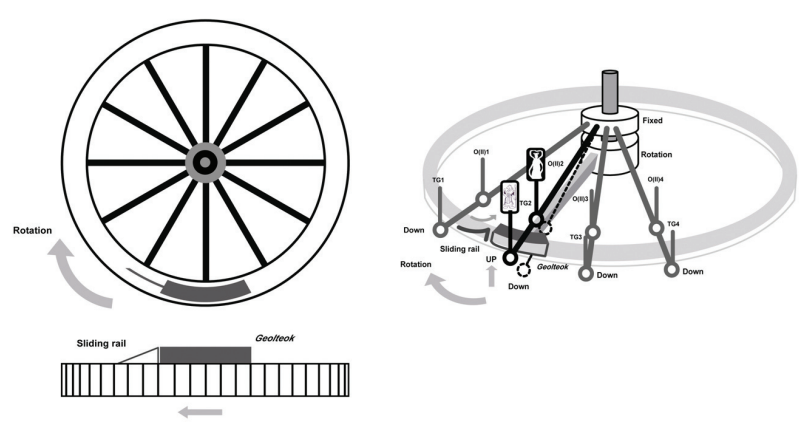

Fig. 3. Keys map of Heumgyeonggaknu's wheel 1.

power to the 12 Ongnyeo (II) and twelve gods on the flatland. The 2nd floor rotation wheel (W2) transfers the power to the time signal puppet device of Sibodae. The 3rd floor rotation wheel (W3) transfers the power to the 4 Ongnyeo (I) and four gods. In the uppermost floor, the power is transferred to the Sun movement device.

The 1st floor rotation wheel transfers the operating signal to the Ongnyeo (II) and twelve gods (Fig. 3). On top of the rotation wheel, the sliding rail and Geolteok (raised spot) were installed. The sliding rail is a device which was also used in Borugaknu ${ }^{15}$ and armillary clock (渾天時計) (Kim 2012). Also, the Geolteok which has the shape of horizontal $\operatorname{rod}($ ' shape) was developed based on the fact that the Sipae of armillary clock is raised to the time-announcing window and is shown continuously. The Ongnyeo (II) and twelve gods were installed at the end of the rods having the shape of umbrella ribs which extend from the central axis so that they can be coupled with the sliding rail and Geolteok. For example, at $\mathrm{O}-\mathrm{Si}$ (午時), the Ongnyeo is raised with the corresponding Sipae by the motion of rotation wheel. 


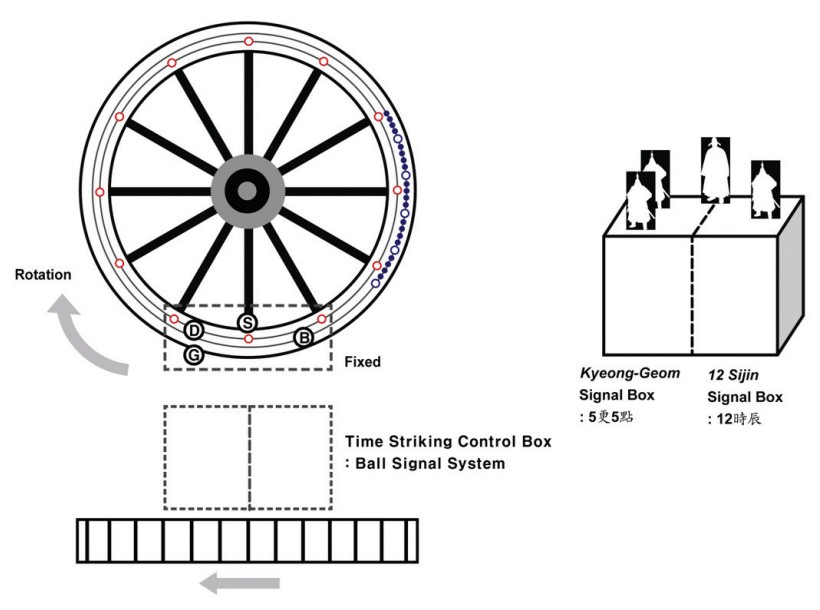

Fig. 4. Keys map of Heumgyeonggaknu's wheel 2.

Among the twelve gods, the $O \sin$ (午神) which was lying face down stands up at this moment. This posture is maintained until it gets out of Geolteok which is on top of the rotation wheel (The Geolteok is installed in $30^{\circ}$ range from the central axis of rotation wheel).

The 2nd floor rotation wheel transfers the signal to the Sasin and 3 Musa (武士, warrior) (Fig. 4). On top of the rotation wheel, the pin-shaped (' I' shape) Geolteok is installed at the position of 12-Si, 5-Gyeong, and 5-Jeom. When the rotation wheel passes Sibodae, the 12 Geolteok which are spaced at an interval of $30^{\circ}$ send the operating signal to Sasin and Jongin (鐘人, striking bell puppet). The Sasin and Jongin face each other, and the Jongin strikes the bell. At night, the 25 Geolteok which express the 5-Gyeong and 5-Jeom send the signal to Goin (鼓人, striking drum puppet) and Jeongin (鉦人, striking gong puppet). The Goin strikes the drum, and the Jeongin strikes the gong. The Sasin and Goin face each other when striking the drum, and the Sasin and Jeongin face each other when striking the gong. The Geolteok signal of 12-Si, 5-Gyeong, and 5-Jeom generates a ball signal which facilitates the striking system that is similar to Borugaknu.

Regarding the method which expresses the Geolteok of 5-Gyeong and 5-Jeom, it seems that the 25 Geolteok were put in so that they match the seasons or the part of rotation wheel where the Geolteok of 5-Gyeong and 5-Jeom are located was replaced as a package. In addition, it is thought that the Jujeon mentioned in ${ }^{『}$ Seongjong Sillok』 is installed in Sibodae, strikes the bell-drum-gong using the Cho (初, beginnings double hours)-Jeong (正, mid-points double hours) signal of wheel 2 and the 5-Gyeong and 5-Jeom signal, and is involved in the detailed motion of time signal puppets. The mechanism of Jujeon seems to have scaled

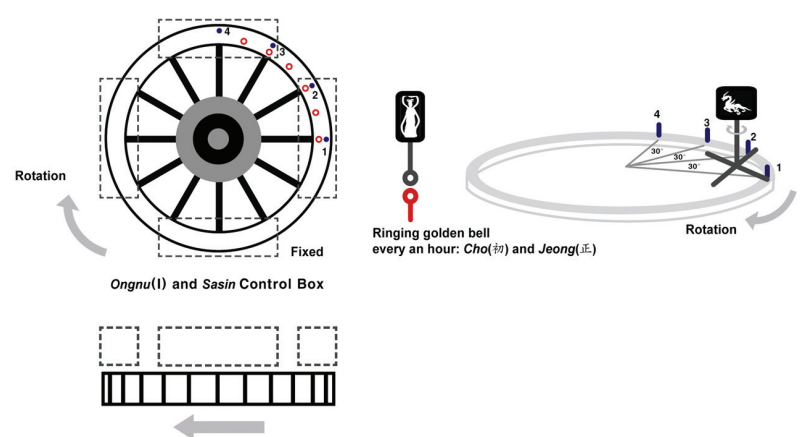

Fig. 5. Keys map of Heumgyeonggaknu's wheel 3.

down and improved the mechanism of Bujeon and Bangmok in Borugaknu.

The 3rd floor rotation wheel transfers the operating signal to the Ongnyeo (I) and four gods (Fig. 5). On top of the rotation wheel is the 5 pin-shaped Geolteok which shows Cho and Jeong every hour, and 4 pin-shaped Geolteok device which rotates the four gods. This Geolteok device moves the gear device of Ongnyeo and four gods which are located in the north, south, east, and west. The Ongnyeo shakes a small bell in the hand at Cho and Jeong every hour, and the four gods rotate $90^{\circ}$ every hour. The Geolteok of rotation wheel is located in $90^{\circ}$ range of rotation wheel so that it operates only at the corresponding time.

\section{CONCLUSIONS}

Heumgyeonggaknu is an automatic water clock which was installed in Heumgyeonggak. Heumgyeong (欽敬) is quoted an expression from Seogyeong (書經) Yojeon (堯 典), 'Admire as high as the sky, and let the people know the subdivisions of the seasons.' ${ }^{16}$ In the 4 directions of Gasan in Heumgyeonggaknu, the Binpungdo (网風圖, landscape of hard farming work scene) of the 4 seasons and the model of Japsang are manufactured. King Sejong fulfilled the meaning of Heumgyeong by reminding the people's difficulty in farming through Binpungdo and the model of Japsang.

In this study, the internal structure of Heumgyeonggaknu was inferred as follows. First, the water clock is thought to consist of the Suho equipped with 2-stage overflow and the 1-stage Pyesuho. Second, the two possibilities that the water clock is located inside or outside Gasan need to be considered. Third, in terms of systematic motion, it is efficient to use a single Giryun to operate the time

\footnotetext{
${ }^{16}$ Sejong sillok, 80:5b:line 13; 欽若昊天, 敬授人時.
} 
signal puppets at the top of the mountain, at the foot of the mountain, and on the flatland. Fourth, the time signal puppets on Sibodae receive the ball signal through Jujeon and inform the 12-Si and Gyeong-Jeom time, which is thought to be an improvement of Bangmok and rod in Borugaknu.

In the conceptual diagram for each floor, emphasis was placed on the signal generation system for the design of detailed operation mechanism. For the operation of Ongnyeo (II) and twelve gods on the flatland of Gasan, the 1st floor rotation wheel was equipped with the device which has the shape of umbrella ribs, sliding rail, and the Geolteok structure which has the shape of rod. For the motion of Sasin and Musa on Sibodae, the 2nd floor rotation wheel was made so that the 12-Si signal, Gyeong-Jeom signal, and the operation of Jujeon are coupled together. For the operation of Ongnyeo (I) and four gods at the top of the mountain, the 3rd floor rotation wheel was made to be the pin-shaped Geolteok structure. Based on the above information, this study is expected to provide basic data for the detailed design of the internal structure of Heumgyeonggaknu.

\section{ACKNOWLEDGMENTS}

This research was supported by Basic Science Research Program through the National Research Foundation of Korea (NRF) funded by the Ministry of Education, Science and Technology (2012R1A1A2003575)

\section{REFERENCES}

Ahn SH, Astronomical Books and Charts Having Been Preserved in the External Branch of the Chosŏn's Royal Library, Gyujanggak, 37, 289-320 (2010).

Hahn YH, Nam MH, Lee SW, Yi MK, Astronomical clocks of the Chosun Dynasty - King Sejong's Heumgyonggaknu, Technology and History, 1, 99-140 (2000).

Hill DR (ed. \& transl.), The book of knowledge of ingenious mechanical devices (Pakistan Hijra Council, Islamabad, 1989), 15-82, Original author: Al-Jazari

Kim DH, Palaces architecture of Seoul (Sigongart, Seoul, 2002), 79.

Kim SH, Lee YS, Lee MS, A study on the operation mechanism of Ongnu, the astronomical clock in Sejong Era, JASS, 28, 79-91 (2011). http://dx.doi.org/10.5140/ JASS.2011.28.1.079

Kim SH, Song I-Yong's armillary clock(Korean Studies Information, Paju-si, 2012), 92, 160.
Lee YS, Kim SH, Structure and conceptual design of a water-hammering-type Honsang for restoration, JASS, 29, 221-232 (2012). http://dx.doi.org/10.5140/ JASS.2012.29.2.221

Nam MH, Jang Yeong-Shil and the striking clepsydra Jagyeongnoo - Revival on the time measuring history of Chosun Period (Seoul National University Press, Seoul, 2002), 192, 241-242.

Needham J, Lu GD, Combridge JH, Major JS, The hall of heavenly records: korean astronomical instruments and clocks 1380-1780 (Cambridge University Press, London, 1986), 76-80.

Park JH, A study on the flow control and escapement system of the water operated mechanical clock in Joseon Dynasty, MS Thesis, Chungbuk National University (2011). 